\title{
Anticancer Properties of Chrysin on Colon Cancer Cells, In vitro and In vivo with Modulation of Caspase-3, -9, Bax and Sall4
}

\author{
Maliheh Bahadori ${ }^{1}$, Javad Baharara ${ }^{2 *}$, Elaheh Amini ${ }^{3}$ \\ ${ }^{1}$ Department of Biology, Damghan Branch, Islamic Azad University, Damghan, Iran \\ ${ }^{2}$ Department of Biology, Research Center For Animal Development Applied Biology, Mashhad Branch, Islamic Azad \\ University, Mashhad, Iran \\ ${ }^{3}$ Department of Animal Biology, Faculty of Biological Sciences, Kharazmi University, Tehran, Iran
}

*Corresponding author: Javad Baharara, Research Department of Biology, Research Center For Animal Development Applied Biology, Mashhad Branch, Islamic Azad University, Mashhad, Iran. Tel: +98-5138437092, Fax: +98-5138437092, E-mail: baharara@mshdiau.ac.ir

Received: November 18, 2015; Revised: February 28, 2016; Accepted: March 14, 2016

Background: The SALL4/Sall4 is constitutively expressed in human and mice. SALL4 mRNA could be used as a marker for the diagnosis of different types of cancers. On the other hand, chrysin has diverse biological properties.

Objectives: In the present study, the effect of the chrysin was investigated on the CT26 colon cancer in vitro and in vivo. Furthermore, the expression levels of the stem cell markers; sall4 and Bax was analyzed, as well.

Materials and Methods: The cytotoxic effects and the type of cell death induced by chrysin were evaluated using a number of biological assays. The apoptotic pathway was examined by caspase-3and caspase- 9 assay. The in vivo antitumor efficacy of chrysin on transplanted CT26 tumor cells in BALB/c mice was investigated. In addition, mRNA expression of sall4, Bax was analyzed with RT-PCR.

Results: MTT assay and morphological characteristics showed that chrysin exerted a cytotoxic effect on CT26 cells in a dose dependent manner with $\mathrm{IC}_{50}=80 \mu \mathrm{g} \cdot \mathrm{mL}^{-1}$. The biological assays have indicated that chrysin administrated cytotoxicity on colon cancer cells through recruitment of the apoptosis. Caspase-3 and caspase- 9 colorimetric assays, in addition to Bax expression analysis, have indicated the involvement of intrinsic apoptotic pathway in the cytotoxic effect of the chrysin. The in vivo assay revealed a remarkable reduction of the colon tumor volume in treated mice $\left(8,10 \mathrm{mg}^{\mathrm{kg}}{ }^{-1}\right)$ as compared to the untreated mice. RT-PCR elucidated that chrysin attenuated tumor volume through down regulation of the sall4 and up-regulation of the Bax.

Conclusions: It was demonstrated that chrysin accomplishes anti-cancer effect on colon cancer cells via induction of the apoptosis and attenuation of the sall4 the expression. These findings introduce chrysin as an efficient apoptosis based therapeutic agent against colon cancer.

Keywords: Apoptosis; Chrysin; Colon cancer; In vivo; Sall4

\section{Background}

Colon cancer is a world-wide health problem and the second most lethal cause of cancer-related death both males and females in the world. It afflicts more than 135,000 patients per year in the world with a incidence rate of $9.4 \%$ and kills more than 55,000 patients (1). Colorectal cancer ranks the second among the most tumor incidence death (2). The incidence of the colorectal cancer is $8.5 \%$ of all cancers and may be related to the lifestyle, obesity, drinking, smoking, as well as other factors (3).

The traditional treatment of the colon cancer includes assisting (application or administration) chemotherapeutic agents and surgery, depending on the location of the metastatic growth, however, the current chemotherapeutic agents induce serious side effects and high toxicity, which also increase the risk of death (4). Chemotherapy is one of the most important treatments for cancer patients. However, the efficacy of the chemotherapeutic drugs is still limited in most solid tumors (5).

There are more than one thousand different drugs that were found to possess significant anticancer properties (6). However, there is still continues demand for 
development of the new anticancer drugs by scientific exploration among a vast variety of synthetic, biological, and natural products (7).

Natural products have been used as an important source of anti-cancer agent, which is estimated to become the major alternative for reducing the cancer death in the $21^{\text {st }}$ century (6).

Pro-apoptotic potential of the natural substances has made them candidate against cancer (8). Plants represent wide variety of phytochemicals with pharmaceutical potential such as poly phenolic, terpenoids, taxol, podophyllum peltatam, and flavonoid compounds. Flavonoids are a class of compound composed of a wide range of plant pigments that are universally present in the fruits and vegetables derived foods. To date more than 4,000 types of biologically active flavonoids have been identified (9). Chrysin is composed of a large class of polyphenolic compounds present in the diet and many herbal products, which have long been associated with a variety of important biochemical and pharmacological activities in the cancer prevention and health promotion $(9,10)$.

A number of studies have shown that chrysin has multiple biological activities, such as anti-inflammation, anti-oxidation and anticancer effects (10). In addition, chrysin has been reported to induce apoptosis in a panel of cancer cell lines, including Hela cervical cancer cells, U937, HL-60, and L1210 leukemia cells. This plant flavonoid was also able to inhibit tumor angiogenesis in vivo, which is a key step in cancer cell metastasis (11). It has been reported that chrysin possess cytotoxic effect on human colon cancer in vitro (9).

The SALL gene family has been found to be involved in tumorigenesis. This gene family is among the most important transcriptional regulators of the stem cells. SALL4 is the most well studied SALL gene associated with the cancer $\mathrm{s}$. Recent studies have shown that SALL4 is an excellent target for assessment of treatment with regard to several types of cancers including, liver, ovarian primitive germ cell, and testicular germ cell tumors (12). The association between SALL4 and OCT4, NANOG, and SOX2 suggests that SALL4 might be a candidate marker for the metastatic germ cell tumors (13). SALL4 was highly expressed in several solid tumors such as breast cancer, germ cell tumor, hepato and gastric cancers, as well as colon carcinoma (14). The role of SALL4 was the focus on carcinogenesis, prevention, treatment of tumor cell lines, and tumor tissues (15).

Our aim was to investigate the anti-cancer effect of chrysin on CT26 colon cancer cells both in vitro and in vivo. Furthermore, we were interested in achieving more insights on the role of chrysin through evaluation of the type of cell death it induces in CT26 cells; in addition to examining the expression of sall4 in colon cancer cells under treatment with chrysin, as well.

\section{Objectives}

In order to have a new insight into the mechanistic cytotoxicity of chrysin, the present study was designed to evaluate whether chrysin was cytotoxic against CT26 colon cancer cells via involvement sall4 and caspase dependent pathway.

\section{Materials and Methods}

\subsection{Cell Culture}

CT26 cells were procured from Pasteur Institute (Tehran, Iran). The cells were cultured in RPMI-1640 medium, supplemented with $10 \%(\mathrm{v} / \mathrm{v})$ Fetal Bovine Serum (FBS, Gibco, Scotland), supplemented with the $1 \%$ antibiotic and incubated at $37^{\circ} \mathrm{C}$ in a humidified atmosphere of $5 \% \mathrm{CO}_{2}$.

\subsection{In vitro Assays}

\subsubsection{Cytotoxicity Assay}

CT26 cells were seeded in a 96- well plate overnight and treated with various concentrations of chrysin $\left(10,20,40,80,100\right.$, and $\left.200 \mu \mathrm{g} \cdot \mathrm{mL}^{-1}\right)$ for 24 $\mathrm{h}$ and 48 h, MTT [3-(4,5-Dimethylthiazol-2-yl)-2,5Diphenyltetrazolium Bromide] (5 mg.mL ${ }^{-1}$ in PBS) was then added to the cells and incubated in the dark for $4 \mathrm{~h}$. Finally, DMSO (dimethyl sulfoxide) was added and optical density was measured at $560 \mathrm{~nm}$ with an microplate spectrophotometer (epoch from Bio Tack, USA) (16).

\subsection{Morphological Assessments}

CT26 cells were treated with various concentrations of chrysin $\left(10,20,40,80,100\right.$, and $\left.200 \mu \mathrm{g} . \mathrm{mL}^{-1}\right)$ for $48 \mathrm{~h}$ and morphological alteration were observed under an inverted microscope (Bio Photonic, Brazil) and photographs were taken.

\subsection{Apoptosis Evaluation Using PI (Propodium Iodide) Staining}

CT26 cells were treated with inhibitory concentrations of chrysin (40 and $80 \mu \mathrm{g} . \mathrm{mL}^{-1}$, respectively) for $48 \mathrm{~h}$. Cells were harvested and washed with PBS. Afterwards, centrifugation was carried out, and the cell pellet was incubated in $500 \mu \mathrm{L}$ of a hypotonic buffer $\left(500 \mu \mathrm{g} \cdot \mathrm{mL}^{-1} \mathrm{PI}\right.$ in $0.1 \%$ sodium citrate and $0.1 \%$ 
Triton X-100) overnight at $4{ }^{\circ} \mathrm{C}$ and flow cytometry was performed using a BDFACS Calibur system (Becton Dickinson, USA) (17).

\subsection{Apoptosis Analysis with Annexin V-FITC and Propodium Iodide Method}

For quantitative evaluation of the chrysin induced apoptosis, Annexin/Propodium Iodide assay (Abcam, UK) was performed according to the manufacture instruction. Briefly, $48 \mathrm{~h}$ after treatment, the CT26 cells were trypsinized and resuspended in $500 \mu \mathrm{L}$ of the $1 \mathrm{X}$ binding buffer. Thereafter, $5 \mu \mathrm{L}$ of Annexin-VFITC and $5 \mu \mathrm{L}$ of Propodium Iodide were added and incubated at room temperature for $5 \mathrm{~min}$, subsequently analysis was conducted using FACSCalibur (Becton Dickinson) flow cytometry (18).

\subsection{Apoptosis Assessment by DAPI Staining}

The cells $\left(1.5 \times 10^{5}\right)$ were seeded in the 6 -well plate and treated with different concentrations of chrysin for 2 days. The cells were washed twice with PBS, and then DAPI [2,2'- diphenyl-1-picrylhydrazyl] was added and incubated for $10 \mathrm{~min}$ in the dark. Finally the cells were washed twice with PBS, resuspended in 1 $\mathrm{mL}$ methanol, and the nuclear morphology was observed under a fluorescence microscopy (18).

\subsection{Caspase-3 and Caspase-9 Asctivity}

In order to detect the induced apoptotic pathway, caspase-9 or caspase-3 colorimetric assay (Abcam-UK) was conducted as per manufacturer's instruction. CT26 cells $\left(2 \times 0^{6}\right)$ were treated with inhibitory concentrations of chrysin for $48 \mathrm{~h}$. Then cells were harvested and mixed with $50 \mu \mathrm{L}$ lysis buffer. Subsequently, $50 \mu \mathrm{L}$ of $2 \mathrm{X}$ reaction buffer was added to each cytosolic extract. Finally, $5 \mu \mathrm{L}$ of DEVD-p-NA (caspase-3 substrate) or LEHDpNA (caspase-9 substrate) were added and the absorbance of samples was read at $405 \mathrm{~nm}$ (19).

\subsection{In vitro Assays}

\subsubsection{Chrysin Preparation}

Chrysin was purchased from Sigma (Cat no. C 80105). To prepare different concentrations of the chrysin $\left(0.5,1,2,4,8\right.$, and $\left.10 \mathrm{mg} \cdot \mathrm{kg}^{-1}\right)$, chrysin was dissolved in $100 \mu \mathrm{L}$ DMSO (Merck, Germany) and was diluted with serum before experiments.

\subsubsection{Animals}

Male BALB/c mice $(25 \pm 5 \mathrm{~g}$, 6 weeks of age $)$ were purchased from Pasteur Institute of Iran, and were fed with chow diet (Tous, Khorasan). The mice were maintained in standard condition at $25 \pm 2^{\circ} \mathrm{C}, 12 \mathrm{~h}$ light/dark cycles with a relative humidity of $55 \pm 5 \%$ and a $12 \mathrm{~h}$ time cycle.

\subsection{In vivo Antitumor Assessment}

To create an allograft colon carcinoma model, CT26 mouse colon cancer cells $\left(1.5 \times 10^{6}\right.$ cells in $0.2 \mathrm{~mL}$ PBS) were injected subcutaneously into the right flank of BALB/c mice ( $\mathrm{n}=5)$. After subcutaneous tumor formation (approximately 7 days) the animals were randomly designated into 5 groups of 5 mice.

The mice were divided into group I (control, administrated PBS orally duration treatment period) and treatment groups received chrysin dissolved in serum including group II (0.5 mg.kg-1 chrysin), group III ( $1 \mathrm{mg} . \mathrm{kg}^{-1}$ chrysin), group IV (2 mg. $\mathrm{kg}^{-1}$ chrysin extract), group V (4 mg.kg-1 chrysin extract), group VI (8 mg.kg-1 chrysin), and group VII (10 mg. $\mathrm{kg}^{-1}$ chrysin) via oral administration once daily for 2 weeks. The mice were sacrificed at the end of 2 week and the tumors were removed, then fresh tumors immediately were kept in an RNAlater solution (Qiagen, Hilden, Germany) at $-20^{\circ} \mathrm{C}$ until extraction.

\subsection{Total RNA Extraction, cDNA Synthesis, and Quantitative RT-PCR}

The untreated and treated tumor tissues were snap frozen in the liquid nitrogen, ground mechanically to a fine powder, and were placed in the new cryogenic tubes. Then, RNA was extracted from colon tissue samples using the RNeasy kit according to manufacturer's instruction (Denazist, IRAN), cDNA was synthesized using cDNA synthesis Kit following to the application of total extracted RNA plus oligo dT $(\text { Oligo(dT) })_{12-18}$ Primer is suitable for use in firststrand cDNA synthesis with reverse transcriptase. The primer hybridizes to the poly(A) tail of mRNA. It is phosphorylated on the $5^{\prime}$ end to facilitate cloning of cDNA) as primers for the synthesis of the first-strand (Parstous, IRAN) as per manufacturer's protocols.

Briefly, cDNA synthesize was performed in the presence of random hexamer or oligo dT, then incubated at $65^{\circ} \mathrm{C}$ for $5 \mathrm{~min}$, and followed by addition RT pre-mix, incubation at $25^{\circ} \mathrm{C}$ for $10 \mathrm{~min}, 50^{\circ} \mathrm{C}$ for $60 \mathrm{~min}$ and $70^{\circ} \mathrm{C}$ for $10 \mathrm{~min}$. PCR reaction was performed in a final volume of $20 \mu \mathrm{L}$ containing: $10 \mu \mathrm{L}$ Taq pre mix, $2 \mu \mathrm{L}$ cDNA, $2 \mu \mathrm{L}$ primer (forward and reverse) and water to a final volume of $20 \mu \mathrm{L}$. The sequences of primers used in this study were as follows: GAPDH (Glyceral dehyde 3-phosphate dehydrogenase) Forward 5'AGATGGTGAAAGTCGGAGTCA-3', Reverse 5'-ATCA TTGATGGCCACCACTTG-3' was used as the housekeeping gene. The forward and reverse primer for Bax 
were designed as 5'-TTTGCTTCAGGGTTTCATCCA3' and 5'-CTCCATGTTACTGTCCAGTTCGT-3', forward and reverse primer for sall4 were as follow $5^{\prime}$ CCAAAGGCAACTTAAAGGTTCAC-3' and 5'-CCGTG AAGACCAATGAGATCTC-3'. Following to the amplification, the PCR products were electrophoresed in a $2 \%$ agarose gel and were evaluated by green viewer staining (20).

\subsection{Statistical Analysis}

Our data were expressed as means \pm SD. Analysis of variance and significant differences were obtained by SPSS 16 software, one-way ANOVA analysis. Values of the $P<0.05$ were considered as significant.

\section{Results}

\subsection{Effect of Chrysin on CT26 Cell Proliferation}

To determine the cytotoxic effect of chrysin, colon cancer were treated with different concentrations of the chrysin ranging from 10 to $200 \mu \mathrm{g} \cdot \mathrm{mL}^{-1}$ for 24 and $48 \mathrm{~h}$. (Figure 1) shows that chrysin treatment inhibited CT26 cell proliferation as a dose dependent manner. The growth rate of CT26 cells in response to $80 \mu \mathrm{g} \cdot \mathrm{mL}^{-1}$ was $48.75 \%$ and $46.68 \%$ at $24 \mathrm{~h}$ and $48 \mathrm{~h}$, respectively. The $\mathrm{IC}_{50}$ for chrysin was determined to be approximately 80 $\mu \mathrm{g} . \mathrm{mL}^{-1}$ which reduced CT26 cells' growth up to $50 \%$ compared to the untreated cells.

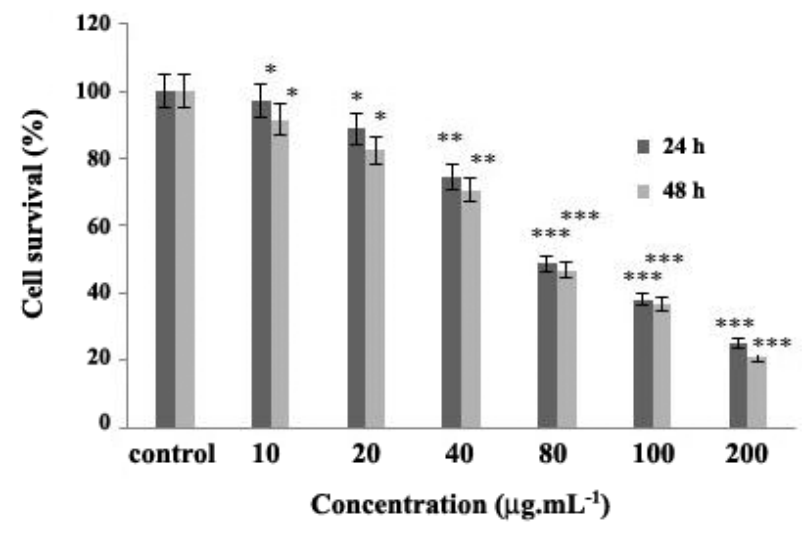

Figure 1. The inhibitory effect of chrysin on CT26 colon cancer cells viability. Cells were treated with a range of chrysin concentration $\left(10,20,40,80,100,200 \mu \mathrm{g} . \mathrm{mL}^{-1}\right)$ for 24 and $48 \mathrm{~h}$, then MTT assay was performed. Data represents as mean $\pm \mathrm{SD}$ of three independent experiments. $p$ value of $* \mathrm{P}<0.05, * * \mathrm{P}<0.01$ and $* * * \mathrm{P}<0.00$ were considered significant

\subsection{Morphological Studies by Inverted and} Fluorescence Microscope

DAPI staining is a reliable apoptotic assay in chemoprevention studies and it helps to observe the apoptotic changes at DNA level. As exhibited in (Figure 2A), specific concentration of chrysin has induced apparent apoptotic morphological alterations, such as a reduction of cell volume, cell shrinkage, and apoptotic body formation in CT26 colon cancer cells
A

control

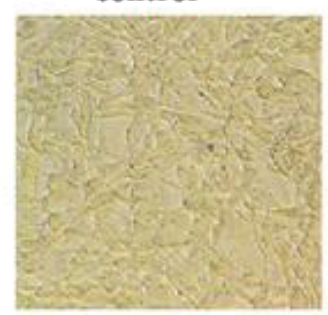

B

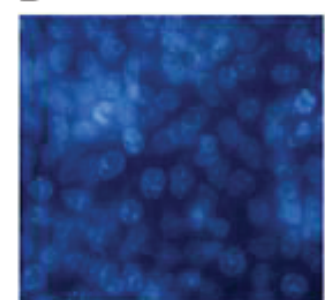

40
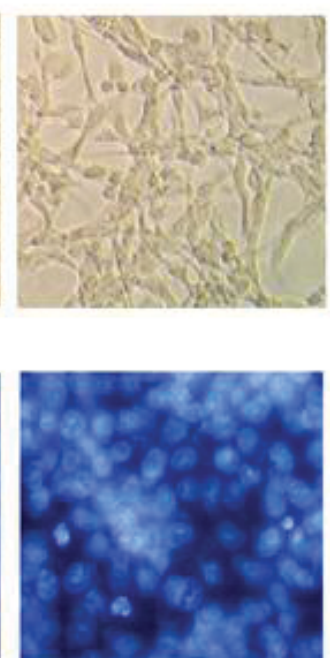

80
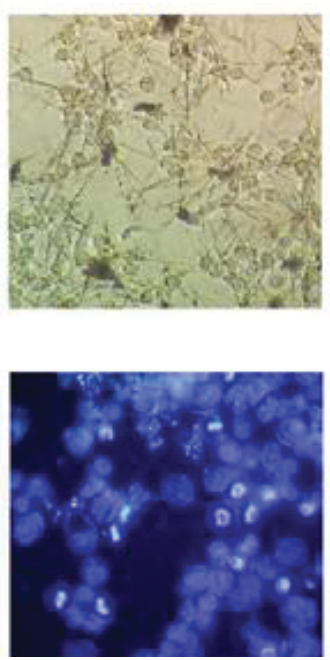

100
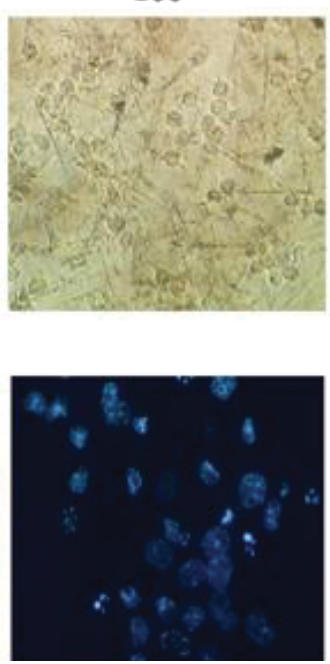

Figure 2. A: CT26 cells morphological changes following to the treatment of the cells with chrysin at different concentrations for $48 \mathrm{~h}$. From the left: control cells, or cells without any treatment, and toward the right: cells that were treated with $40 \mu \mathrm{g} \cdot \mathrm{mL}^{-1}, 80 \mu \mathrm{g} \cdot \mathrm{mL}^{-1}$, and $100 \mu \mathrm{g} \cdot \mathrm{mL}^{-1}$ of chrysin for $48 \mathrm{~h}$, respectively. B: The fluorescence profiles of the corresponding CT26 cells treated with the same concentration of chrysin and stained with DAPI. Arrows indicate DNA fragmentation in the corresponding treated cells group 
showing that apoptosis has been triggered under exposure with growth inhibitory concentration of the chrysin. DAPI staining showed that chrysin has induced chromatin condensation as a typical apoptotic feature in the inhibitory concentrations of chrysin (Figure 2B).

\subsection{Detection of Apoptosis by PI Flow Cytometry}

The apoptosis inducing effect of the chrysin was analyzed using flow cytometry according to the exclusion of PI by viable cells. As shown in the (Figure 3A), chrysin treatment has significantly increased the sub-G1 peak, which is an indicator of apoptosis induction resulted from DNA fragmentation, and endonuclease activation that is considered as a crucial anti-proliferative mechanism of chrysin treatment.

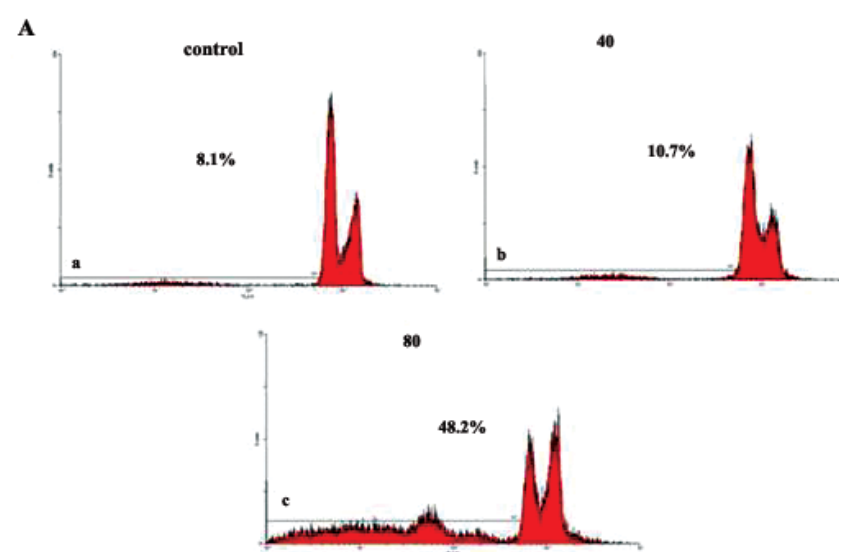

B

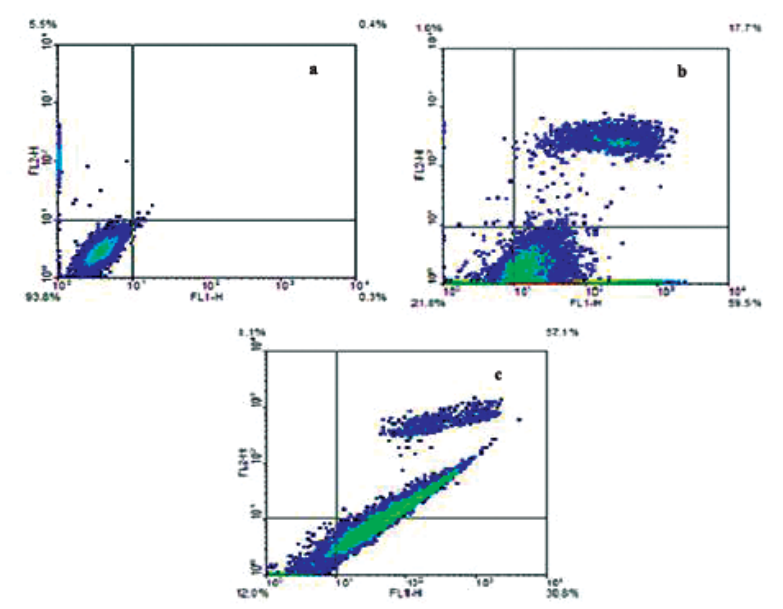

Figure 3. A: Flow cytometry histograms of apoptosis induce by PI method in CT26 cells, a: untreated cells, b: cells treated with 40 $\mu \mathrm{g} \cdot \mathrm{mL}^{-1}$ chrysin, and c: treated with $80 \mu \mathrm{g} \cdot \mathrm{mL}^{-1}$ chrysin for $48 \mathrm{~h}$. Apoptotic cell death can be quantified by DNA content frequency histograms (sub-G1 peak). B: Quantification of apoptosis cell death by Annexin-V/PI double-staining assay. Flow cytometry charts of CT26 cells, a: untreated or control, b: treated with $40 \mu \mathrm{g} \cdot \mathrm{mL}^{-1}$ chrysin, and c: $80 \mu \mathrm{g} \cdot \mathrm{mL}^{-1}$ chrysin, respectively

\subsection{AnnexinV FITC Assay}

The apoptotic alterations of the plasma membrane can be perceived through Annexin V-FITC (Fluorescein isothiocyanate) staining (18). To verify the apoptotic morphological changes as a result of treatment with chrysin $(80$ $\left.\mu \mathrm{g} . \mathrm{mL}^{-1}\right)$, annexin V-FITC/PI staining was performed. Flow cytometry diagrams determined that the percentage of annexin positive cells were gradually increased as the concentration of the chrysin was increased; from the live cells, to an early apoptotic, the late apoptotic, as well as necrotic cell death where it enhanced remarkably. Hence, the percentage of apoptotic cells was $0.7 \%$ in the control group, $77.2 \%$ in $80 \mu \mathrm{g} . \mathrm{mL}^{-1}$ and $85.7 \%$ in $100 \mu \mathrm{g} . \mathrm{mL}^{-1}$ treated groups, which is the hallmark of apoptosis induction under treatment with $\mathrm{IC}_{50}$ concentration of the chrysin on CT26 colon tumor cells (Figure 3B).

\subsection{Determination of the Type of Apoptotic Pathway Induced by Caspase -3 and -9 Assay}

To determine the type of apoptotic pathway involved, the level of caspase -3 and -9 were calculated colorimetrically. Our results elucidated that cytotoxic effect of chrysin administrated through an increase in the caspase- 3 and caspase- 9 activity in the treated cells in a concentration-dependent manner as compared with the control cells. Therefore, it could be concluded that chrysin exerted its cytotoxicity effects on the CT26 colon cancer cells via intrinsic apoptotic pathway (Figure 4).

\subsection{Effect of Chrysin on the Tumor Volume}

As was shown, chrysin suppresses tumor cell growth. We have further investigated its antitumor

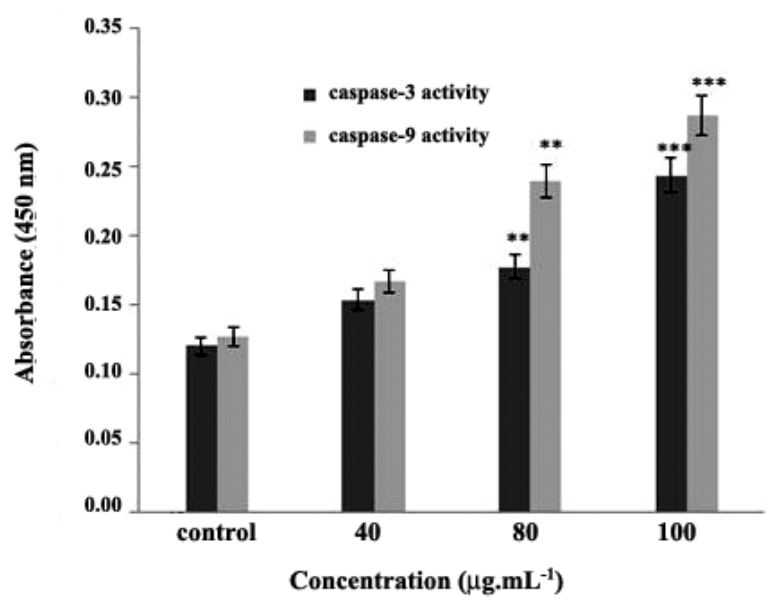

Figure 4. Caspase- 3 and Caspase-9 activities in the CT26 cells treated with $40,80,100 \mu \mathrm{g} \cdot \mathrm{mL}^{-1}$ of chrysin. Values are expressed as the mean $\pm \mathrm{SD}$ of the triplicate experiment. Significant differences were compared with the control at ${ }^{*} \mathrm{p}<0.05$ by t-test 
effects in a mouse model of the colon cancer. As it is shown in (Figure 5A), at the terminalexperiment, the oral administration of chrysin at 8 and $10 \mathrm{mg} \cdot \mathrm{kg}^{-1}$ has led to a significant regression in the tumors' volume as compared to the control group treated with the vehicle solution (i.e. PBS).

\subsection{Effect of Chrysin on Sall4 and Bax mRNA Expression in vivo}

To investigate the involvement of Bax in the induction of apoptosis in vivo in the CT26 colon cancer cells, cells were treated with 50\% inhibitory concentrations of chrysin, then expression of Bax family as proapoptotic factors was assessed using RT-PCR. Figure 5B showes that chrysin has up-regulated the level of Bax in a dose dependent manner. As well, analysis of sall4 transcriptional levels showed that treatment with chrysin has down regulated sall4 mRNA level dose dependently in colon cancer cells.

\section{Discussion}

In our study, the anticancer efficacy of the chrysin against CT26 colon cancer cells was investigated. Our observation revealed that chrysin possess moderate cytotoxic effect on CT26 cells in a concentration

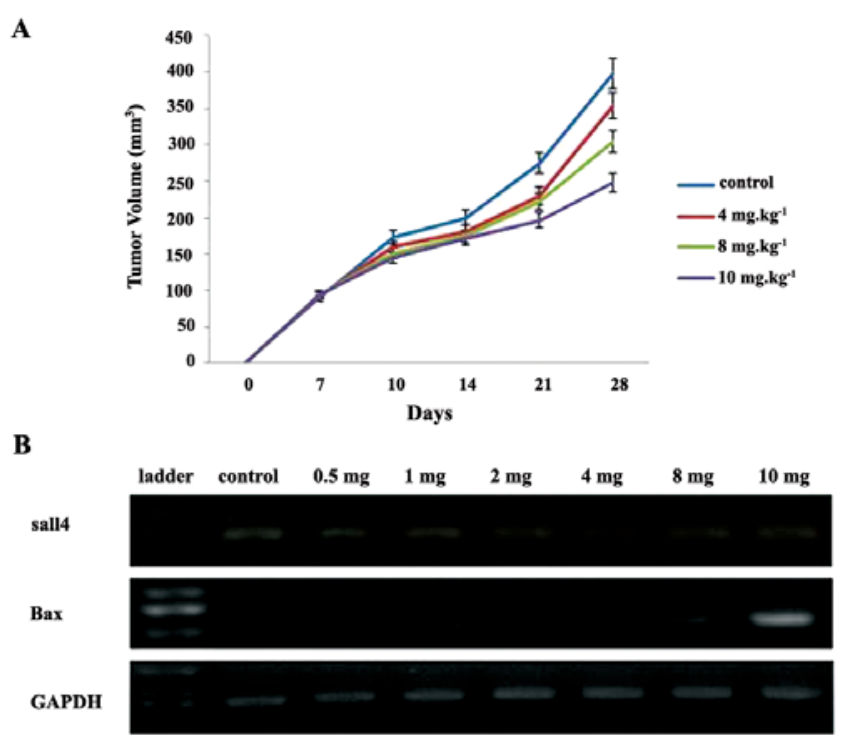

Figure 5. A: Relative variations in the tumors volume within different groups during 28 days. Tumor volumes were measured following to the exposure of mice to the $0.5,1,2,4,8,10 \mathrm{mg} \cdot \mathrm{kg}^{-1}$ chrysin and were monitored every day using a digital caliper, and relative variations of the growth inhibition of tumors in different groups were measured. B) Effects of chrysin on sall4 and Bax mRNA levels in CT26 cells. Transplanted BALB/c mice were treated with $0.5,1,2,4,8$, and $10 \mathrm{mg} \cdot \mathrm{kg}^{-1}$ chrysin which demonstrated the involvement of sall4 expression and pro apoptotic effect of chrysin on CT26 cells dependent manner. In addition, the findings from fluorescence microscopy, Annexin-PI and caspase assays showed that the cytotoxicity of chrysin was related to the recruitment of the intrinsic pathway of apoptosis cell death.

Natural products have been used as an alternative medicine from the ancient time and plant-derived compounds were considered as the safe modalities that offer multitude benefits for preventing chronic diseases such as cancer $(21,22)$. Chrysin is a natural flavonoid presented in many plant extracts, including blue passion flower (Passiflora caerulea), honey, and propolis (23). It is a natural, biologically active compound that possesses potent anti-inflammatory, anticancer, and antioxidant properties (24).

The pro apoptotic effect of chrysin has been reported in breast carcinoma, cervical cancer, leukemia, lung cancer (NSCLC), and colon cancer in vitro (9). A study by Zhang et al. has demonstrated that chrysin and tetraethyl bis-phosphoric ester (one of chrysin derivatives) exhibited potential anti-cancer effects in human cervical carcinoma cells (25).

The survey carried out by Shao et al. has revealed that chrysin induced growth inhibition and apoptosis in the cultured lung cancer; the A549 cells, along with activation of AMP-activated protein kinase (AMPK) (26). Recently, a synergism between doxorubicin and chrysin administrated cancer cell death has been shown through chemosensitizing these cells to chemotherapy via GSH depletion in the cancer cells (27).

In this study, we have investigated the anti-cancer effect of chrysin against colon cancer cells in vivo. CT26 cell line was injected subcutaneously into mice for allograft colon cancer model formation and assessment of the anti-cancer efficacy of chrysin against colon cancer. The tumor volume measurement has indicated that chrysin (i.e., 4, 8, 10 mg. $\mathrm{kg}^{-1}$ ) dose dependently reduces the tumor volume. In the present study we attempted to further address the anti-cancer potential of chrysin and the involved molecular mechanisms. The in vivo results confirmed that regression of mouse CT26 tumor volume under exposure to chrysin was associated with apoptotic death via up regulation of Bax mRNA level in concentration of $10 \mathrm{mg} \cdot \mathrm{kg}^{-1}$.

The anti-cancer potential of chrysin has also been reported in a variety of cell lines (28) and animals (29). Other previous studies have shown that chrysin sensitizes apoptosis induced cell death by tumor necrosis factor (TNF), or tumor necrosis factor-related apoptosis-inducing ligand (TRAIL) in various human cancer cells (30), suggesting the therapeutic potential of the chrysin for treatment of human cancers. Izuta and his 
colleagues have found that chrysin triggers caspase-3 activation, mitochondrial membrane depolarization and mitochondrial cytochrome c release (31).

Pal-Bhadra and coworkers have shown the effect of chrysin and its analogues on cell viability and cell cycle analysis by MTT assay and flow cytometry. They elucidated that chrysin possess potent in vitro anti-cancer activity via suppression of the cell proliferation, induction $\mathrm{G}_{1}$ cell cycle arrest, along with the up regulation of $\mathrm{p} 21$, in addition to reduction of cyclin $\mathrm{D} 1$ and $\mathrm{Cdk} 2$ protein levels (32).

Associated with the analysis of sall4 expression; in most human malignancies, SALL4 might be over expressed and potentially used as a diagnostic marker. Similarly, Cao et al have reported the over expression of SALL4 protein as a novel diagnostic marker for germ cell tumors such as testis and ovary as well as other metastatic germ cells' tumors (33). Forghani Fard et al. (2013) have reported that sall4 is one of the genes involved in the colon carcinogenesis (34).

A well, in this study we assessed whether anti-cancer effect of chrysin on CT26 cells is associated with sall4 expression or not. Hence, RT-PCR analysis was performed and the mRNA profile of sall4 has demonstrated that chrysin exerts cytotoxicity on CT26 colon tumor cells via down regulation of the sall4 expression. However, sall4 down regulation could be considered as a palliative marker for treatment of colon cancer.

In conclusion, we have elucidated that chrysin inhibited the proliferation and induced apoptosis in CT26 colon cancer cells and reduction of tumor volume in animal model. Moreover, human clinical trials are necessary to make it clear whether this flavonoid could be proposed as a possible natural agent for the prevention and treatment of the human colon cancer.

\section{Acknowledgments}

This research was supported by Islamic Azad University of Mashhad (Research Center of the Applied Biology, Kharazmi Institute).

\section{References}

1. Wargovich MJ, Morris J, Brown V, Ellis J, Logothetis B, Weber R. Nutraceutical use in late-stage cancer. Cancer Metastasis Rev. 2010;29(3):503-510. DOI: 10.1007/s10555-010-9240-5

2. Jemal A, Bray F, Center MM, Ferlay J, Ward E, Forman D. Global cancer statistics. CA Cancer J Clin. 2011;61(2):69-90. DOI: $10.3322 /$ caac. 20107

3. Jung GR, Kim KJ, Choi CH, Lee TB, Han SI, Han HK, et al. Effect of betulinic acid on anticancer drug-resistant colon cancer cells. Basic Clin Pharmacol Toxicol. 2007;101(4):277285. DOI: $10.1111 / \mathrm{j} .1742-7843.2007 .00115 . x$
4. Ohe Y. Treatment-related death from chemotherapy and thoracic radiotherapy for advanced cancer. Panminerva Med. 2002;44(3):205-212. DOI: 10.1371/journal.pone

5. Mushiake H, Tsunoda T, Nukatsuka M, Shimao K, Fukushima $\mathrm{M}$, Tahara H. Dendritic cells might be one of key factors for eliciting antitumor effect by chemoimmunotherapy in vivo. Cancer Immunol Immunother. 2005;54(2):120-128. DOI: 10.1007/s00262-004-0585-x

6. Mukherjee AK, Basu S, Sarkar N, Ghosh AC. Advances in cancer therapy with plant based natural products. Curr Med Chem. 2001;8(12):1467-1486. DOI: 10.2174/0929867013372094

7. Parsaee H, Asili J, Mousavi SH, Soofi H, Emami SA, TayaraniNajaran Z. Apoptosis Induction of Salvia chorassanica Root Extract on Human Cervical Cancer Cell Line. Iran J Pharm Res. 2013;12(1):75-83.

8. Amini E, Baharara J, Nikdel N, Salek Abdollahi F. Cytotoxic and pro-apoptotic effects of Honey Bee Venom and Chrysin on Human Ovarian Cancer Cells. Asia Pac J Med Toxicol. 2015;4:68-73. DOI: 10.1186/1472-6882-14-334

9. Khoo BY, Chua SL, Balaram P. Apoptotic effects of chrysin in human cancer cell lines. Int J Mol Sci. 2010;11(5):2188-2199. DOI: $10.3390 /$ ijms 11052188

10. Middleton EJr, Kandaswami C, Theoharides TC. The effects of plant flavonoids on mammalian cells: implications for inflammation, heart disease, and cancer. Pharmacol Rev. 2000;52(4):673-751.

11. Ren J, Cheng H, Xin WQ, Chen X, Hu K. Induction of apoptosis by 7-piperazinethylchrysin in HCT-116 human colon cancer cells. Oncol Rep. 2012;28(5):1719-1726. DOI: 10.3892/or.2012.2016

12. Gao C, Kong NR, Chai L. The role of stem cell factor SALL4 in leukemogenesis. Crit Rev Oncog. 2011;16(1-2):117-127. DOI: 10.1615/CritRevOncog.v16.i1-2.110

13. Cao D, Humphrey PA, Allan RW. SALL4 is a novel sensitive and specific marker for metastatic germ cell tumors, with particular utility in detection of metastatic yolk sac tumors. Cancer. 2009;115(12): 2640-2651. DOI: 10.1002/cncr.24308

14. Lin J, Qian J, Yao DM, Qian W, Yang J, Wang CZ, et al. Aberrant hypomethylation of SALL4 gene in patients with myelodysplastic syndrome. Leuk Res. 2013;37(1):71-75. DOI: $10.1016 /$ j.leukres.2012.10.014

15. Han SX, Wang JL, Guo XJ, He CC, Ying X, Ma JL, et al. Serum SALL4 is a novel prognosis biomarker with tumor recurrence and poor survival of patients in hepatocellular carcinoma. J Immunol Res. 2014;2014:1-7. DOI: 10.1155/2014/ 262385

16. Nobili S, Lippi D, Witort E, Donnini M, Bausi L, Mini E, et al. Natural compounds for cancer treatment and prevention. Pharmacol Res. 2009;59(6):365-378. DOI: 10.1016/j.phrs. 2009.01.017

17. Amini E, Nabiuni M, Baharara J, Parivar K, Asili J. In vitro pro apoptotic effect of crude saponin from Ophiocoma erinaceus against cervical cancer. Iran J Pharmaceutical Res. 2016;in press

18. Namvar F, Rahman HS, Mohamad R, Baharara J, Mahdavi M, Amini E, et al. Cytotoxic effect of magnetic iron oxide nanoparticles synthesized via seaweed aqueous extract. Int J Nanomedicine. 2014;19(9):2479-2488. DOI: 10.2147/IJN.S59661119 
19. Thangam R, Sathuvan M, Poongodi A, Suresh V, Pazhanichamy $\mathrm{K}$, Sivasubramanian S, et al. Activation of intrinsic apoptotic signaling pathway in cancer cells by Cymbopogon citratus polysaccharide fractions. Carbohydr Polym. 2014;107:138-150. DOI: 10.1016/j.carbpol.2014.02.039

20. Saha SK, Sikdar S, Mukherjee A, Bhadra K, Boujedaini N, Khuda-Bukhsh AR. Ethanolic extract of the Goldenseal, Hydrastis canadensis, has demonstrable chemopreventive effects on HeLa cells in vitro: Drug-DNA interaction with calf thymus DNA as target. Environ Toxicol Pharmacol. 2013;36(1):202-214. DOI: 10.1016/j.etap.2013.03.023

21. Aggarwal BB, Banerjee S, Bharadwaj U, Sung B, Shishodia $\mathrm{S}$, Sethi G. Curcumin induces the degradation of cyclin E expression through ubiquitin-dependent pathway and up-regulates cyclin-dependent kinase inhibitors p21 and p27 in multiple human tumor cell lines. Biochem Pharmacol. 2007;73(7):1024-1032. DOI: 10.1016/j.bcp.2006.12.010

22. Mehta RG, Murillo G, Naithani R, Peng X. Cancer chemoprevention by natural products: how far have we come? Pharm Res. 2010;27(6):950-961. DOI: 10.1007/s11095-010-0085-y

23. Li X, Huang Q, Ong CN, Yang XF, Shen HM. Chrysin sensitizes tumor necrosis factor-alpha-induced apoptosis in human tumor cells via suppression of nuclear factor-kappaB. Cancer Lett. 2010;293(1):109-116. DOI: 10.1016/j.canlet.2010.01. 002

24. Pushpavalli G, Kalaiarasi P, Veeramani C, Pugalendi KV. Effect of chrysin on hepatoprotective and antioxidant status in D-galactosamine-induced hepatitis in rats. Eur J Pharmacol. 2010;631(13):36-41. DOI: 10.1016/j.ejphar.2009.12.031

25. Zhang T, Chen X, Qu L, Wu J, Cui R, Zhao Y. Chrysin and its phosphate ester inhibit cell proliferation and induce apoptosis in Hela cells. Bioorg Med Chem. 2004;12(23):6097-6105. DOI: 10.1016/j.bmc.2004.09.013

26. Shao JJ, Zhang AP, Qin W, Zheng L, Zhu YF, Chen X. AMPactivated protein kinase (AMPK) activation is involved in chrysin-induced growth inhibition and apoptosis in cultured A549 lung cancer cells. Biochem Biophys Res Commun. 2012;423(3):448-453. DOI: 10.1016/j.bbrc.2012.05.123
27. Brechbuhl HM, Kachadourian R, Min E, Chan D, Day BJ. Chrysin enhances doxorubicin-induced cytotoxicity in human lung epithelial cancer cell lines: the role of glutathione. Toxicol Appl Pharmacol. 2012;258(1):1-9. DOI: 10.1016/j.taap.2011.08.004

28. Yang F, Jin H, Pi J, Jiang JH, Liu L, Bai HH, et al. Anti-tumor activity evaluation of novel chrysin-organogermanium (IV) complex in MCF-7 cells. Bioorg Med Chem Lett. 2013;23(20):5544-5551. DOI: 10.1016/j.bmcl.2013.08.055

29. Miyamoto S, Kohno H, Suzuki R, Sugie S, Murakami A, Ohigashi $\mathrm{H}$, et al. Preventive effects of chrysin on the development of azoxymethane-induced colonic aberrant crypt foci in rats. Oncol Rep. 2006;15(5):1169-1173. DOI: 10.3892/or. 15.5.1169

30. Li X, Wang JN, Huang JM, Xiong XK, Chen MF, Ong CN, et al. Chrysin promotes tumor necrosis factor (TNF)-related apoptosis-inducing ligand (TRAIL) induced apoptosis in human cancer cell lines. Toxicol In Vitro. 2011;25(3): 630635. DOI: 10.1016/j.tiv.2010.12.013

31. Izuta H, Shimazawa M, Tazawa S, Araki Y, Mishima S, Hara H. Protective effects of Chinese propolis and its component, chrysin, against neuronal cell death via inhibition of mitochondrial apoptosis pathway in SH-SY5Y cells. J Agric Food Chem. 2008;56(19):8944-8953. DOI: 10.1021/jf8014206

32. Pal-Bhadra M, Ramaiah MJ, Reddy TL, Krishnan A, Pushpavalli SN, Babu KS, et al. Plant HDAC inhibitor chrysin arrest cell growth and induce p21WAF1 by altering chromatin of STAT response element in A375 cells. BMC Cancer. 2012;12: 180-189. DOI: 10.1186/1471-2407-12-180

33. Kobayashi D, Kuribayashi K, Tanaka M, Watanabe N. Overexpression of SALL4 in lung cancer and its importance in cell proliferation. Oncol Rep. 2011;26(4):965-970. DOI: 10.3892/ or.2011.1374

34. Forghanifard MM, Moghbeli M, Raeisossadati R, Tavassoli A, Javdani Mallak A, Boroumand-Noughabi S, et al. Role of SALL4 in the progression and metastasis of colorectal cancer. $J$ Biomed Sci. 2013;20:6-12. DOI: 10.1007/s10555-010-9240-5 